\title{
Panuntunán Na Ortograpiya Éd saltTAN PANGASINAN 2012. \\ MANILA: KOMISYON SA WIKANG FILIPINO, 2012. XV + 20 PP.
}

\section{Erwin Soriano FERNANDEZ}

Abung na Panagbasay Pangasinan, Philippines

win1tree@yahoo.com

\section{Book review}

The haste in which this orthography was made contributed, no doubt, to some errors and misconceptions that proliferate in the pages of this booklet. It aims to establish orthographic rules on Pangasinán, a language spoken by at least two and a half million speakers in the province of Pangasinán in Northwest Luzon, Philippines. By all means this booklet must be welcomed by all Pangasináns and non-Pangasináns alike as it heralds the revitalization of Pangasinan, which has been pronounced as a dying language due to national language policy and the apathy of the people themselves.

That it was done under the auspices of the Komisyon sa Wikang Filipino [KWF or Commission on the Filipino Language] raises a number of questions. The rules are patterned after the guidelines set for Filipino making Pangasinán a mere copycat without its own distinctive character as unique language. Pangasinán as a language has its orthographic history whose speakers and more so its writers developed an inimitable custom for writing that makes it different from other languages. To agree and to accept the Tagalog, Filipino, way of orthography is to insult the struggles and innovations made in the name of the Pangasinan language. Messages that should have been translated to Pangasinán remain in Tagalog particularly that of the Philippine Department of Education (DepEd) secretary and the KWF director-general.

More dubious is the role of the Pangasinán Provincial Tourism Office (PPTO) in the making of the booklet. While there must have been a need for personnel that could easily be loaned from this office, this could have been supplied by the Pangasinán Historical and Cultural Commission (PHCC) whose commissioners gather when there is a meeting or two without the concomitant office and personnel designated to this agency. Its ad-hoc personality makes it difficult to run programs that could have stimulated discussion such as this on orthography through conferences, forums and meetings under its guidance and supervision.

It is true that the PHCC helped in the crafting when one of its commissioners became one of the validators and even wrote a short essay included in the booklet. The latter, however, instead of enlightening the origins of Pangasinán, obfuscated it 
by mentioning unsubstantiated claims that Pangasináns came from Thailand and Flores Island in Indonesia or that Dutch came to colonize after the Spaniards (ix).

Now to its substance, the makers of this orthography have confused the sounds of Pangasinan with English so that the pronunciation of letters either vowel or consonant is based not on Pangasinán phonics but on English. Thus, Pangasinán school children are taught "ey", "bi", "si", "di", "e/i", "ef", "ji", "eych", "ay", "jey",

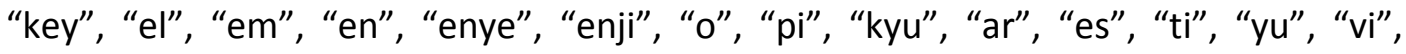
"dobolyu", "eks", "way" and "zi" for a, b, c, d, e, f, g, h, i, j, k, l, m, n, ñ, ng, o, p, q, r, s, $t, u, v, w, x, y$ and $z$ (1). When I raised the issue that Pangasinán must be studied on its own terms in a forum, the late head of KWF Division of Linguistics shrugged it off and said it would be very difficult to do that. The result is a set of orthographic rules with phonics borrowed from English. The distinctive schwa sound, ə, which is peculiar in Pangasinan, is never discussed.

There are four sets of orthographic rules stipulated in the guidelines. The first set deals with rules on pronunciation using English phonics but under this are misplaced orthographic rules on borrowing words from other Philippine languages, words from foreign languages, and words from Spanish (2-6). The second set of rules deals with rules on syllabication (6-9). The third set tackles rules on borrowing, which somehow repeat what are stated in the first set: borrowed words from Philippine and foreign languages must remain in their original spelling while those from Spanish must be spelled in Pangasinán (i.e., asfalto to aspalto, diccionario to diksyonaryo etc.) although Spanish words beginning in " $\mathrm{e}$ " or with " $\mathrm{o}$ " must retain these letters if borrowed (i.e., estudiante to estudyante not istudyante, politica to politika not pulitika) (9-11). It also rules that proper, technical, scientific and mathematical terms must remain in their original borrowed spelling (11-12), which I think - with the exception of proper names - is a lazy way out of the challenge in intellectualizing the language.

The fourth set, "Other rules", contains rules on the use of "na" and " $n$ ", modification or assimilation of verbs, adjectives or nouns through affixes, the use of ligatures " $y a$ " and " $a$ ", the use of " $y$ " in the shortening of words or contractions, the usage of " $u$ " and "o", the use of " $w$ " instead "o" in "oa" and "ua", which is used in the old Castillian orthography and the use of " $w$ " between " $u$ " and "e" (i.e., buer to buwer) (12-18).

On the proper use of ligatures "ya" and "a", the booklet is a clear manifestation of not following the rule $(4,6)$ simply because it is contradictory and goes against the established norms. It says that "a" is to be used when it follows a word ending in consonant or it is before a word beginning in consonant while "ya" is to be used after words ending in vowels or semi-vowels (i.e, " $w$ " and " $y$ "). Convention has it that "a" is used before a word that begins in consonant while "ya" is used before a word that starts in vowel. This rule is evidently seen in the translation and publication of the gospel of St. Luke in 1887 into Pangasinan, the first among Philippine languages that opened the doors for translation of the Bible, by Nicolas Manrique Alonzo Lallave, a defrocked Spanish Dominican priest turned protestant. 
It is curious, however, that last in this set is a rule that disallows the use of "saray" in plural form of nouns, which is outright wrong. This is contrary to the consistency rule in which "saray", which is the plural form of "say", the article, must be consistent with the sense of the substantive. Hence, the first example given, "say pituran lalaki" [the seven men] must be "saray pituran lalaki" [the seven men] (18). I tried to understand as to why this rule is included when it is obvious that the rule is incorrect and it came to me that the basis is the application of a rule for another language.

The use of accent in the pronunciation of words as advocated by the booklet should be encouraged. Nonetheless, the use of ['] or acute accent in indicating the stress on a syllable and the $ə$ sound in é is confusing. It can be replaced by another symbol, [ "] the diaeresis or umlaut - as advocated by one writer - or designate "e" as the $ə$ sound with e that can still be used for other sounds since only a number of words have the $ə$ (i.e., tawen, berbér, ebá etc.).

The rush in which this is undertaken is shown in the typographical mistakes (7, 11).

But altogether these imperfections are minimal compared to the grievous lack of acknowledgements due to their respective authors since they are not cited or mentioned giving the impression that this is wholly an original undertaking. There were efforts to standardize the Pangasinán orthography since the 1930s beginning with the works of Pablo Mejia, the so-called prince of Pangasinán poetry. A poetessscholar of Pangasinán literature also proposed orthography for Pangasinan. In 2008 a forum was held on Pangasinán orthography in a university in Dagupan. Ignorance - or even intellectual dishonesty - can never be made an excuse for any enterprise as critical as this. 